\title{
PENDIDIKAN BERBASIS BUDAYA LOKAL SUKU BOTI: STUDI KASUS DI SDN-SMPN SATU ATAP OEFAU DESA BOTI NUSA TENGGARA TIMUR
}

\author{
Herawati Sandiningtyas, Bambang Budi Wiyono \\ Universitas Negeri Malang, Jalan Semarang 5 Malang 65145 \\ Email: herawati.sandiningtyas@gmail.com
}

\begin{abstract}
Education is the basic foundation of a nation in order to increase welfare of nation and all its citizen. Heterogenitas was supplemented by indonesian people who live in the islands, made the country various culture, its uniqueness that is different from others. One of them is the oldest ethnic who live on the island of Timor, Boti ethnic. The ethnic has many unique so it became a cultural tourism of East Nusa Tenggara. Society still holds customs and traditions prevailing. Therefore, SDN and SMPN Satu Atap Oefau residing in the Boti to keep the existence of the customs that still exist by integrating local culture into the local content subjects, extracurricular and intracurricular. This research used qualitative research with a case study. Education without culture causes values local wisdom fade that while there is a culture without education will not give long term benefits.
\end{abstract}

Keywords: education, culture, local culture based education

\begin{abstract}
Abstrak: Pendidikan merupakan landasan dasar dalam sebuah bangsa demi peningkatan kesejahteraan bangsa dan seluruh masyarakatnya, dengan heterogenitas tinggi ditambah lagi dengan masyarakat indonesia yag hidup di negara kepulauan, menjadikan adanya berbagai macam budaya, kekhasan yang melekat di setiap sisi kehidupan masyarakatnya yang berbeda satu dengan yang lain. Salah satunya adalah Suku tertua yang hidup di pulau Timor, yaitu suku Boti. Suku ini memiliki banyak keunikan sehingga menjadi daya tarik wisata budaya Nusa Tenggara Timur. Masyarakat masih memegang adat istiadat dan tradisi yang berlaku. Oleh sebab itu, SDN dan SMPN Satu Atap Oefau yang berada di wilayah Boti Dalam ingin tetap menjaga eksistensi adat istiadat yang masih ada dengan mengintegrasikan budaya lokal yang ada ke dalam mata pelajaran muatan lokal, ekstrakurikuler maupun intrakurikuler. Penelitian menggunakan penelitian kualitatif dengan rancangan studi kasus. Pendidikan tanpa adanya budaya menyebabkan lunturnya nilai-nilai kearifan lokal yang ada sedangkan budaya tanpa pendidikan tidak akan memberi manfaat jangka panjang.
\end{abstract}

Kata kunci: pendidikan, budaya, pendidikan berbasis budaya lokal

Indonesia merupakan daerah yang memiliki heterogenitas dan multikultural yang tinggi. Jumlah daerah yang berbentuk kepulauan sampai kepada suku-suku yang masih tinggal di daerah yang jauh dari kehidupan modern. Dalam menghadapi perkembangan jaman yang berubah disertai adanya persaingan global, maka pendidikan menjadi salah satu upaya dalam mengubah cara berfikir dan sudut pandang masyarakat yang tinggal di tempat terpencil. Masyarakat sadar arti pendidikan yang dapat membantu mereka mengatasi permasalahan dalam lingkungan mereka namun tanpa mengubah budaya dari nenek moyang mereka. Undangundang Nomor 20 Tahun 2003 tentang Sistem Pendidikan Nasional mengatur berbagai macam hal dari pendidikan dasar sampai pendidikan tinggi, yang juga merupakan investasi pembangunan bangsa dan negara demi kemajuan bangsa baik masa kini maupun untuk masa yang akan datang. Hal tersebutlah yang menjadi latar belakang permasalahan pendidikan bangsa Indonesia yang harus diselesaikan dengan pemerataan dalam bidang pendidikan kepada semua anak bangsa. Pendidikan merupakan landasan dasar dalam 
sebuah bangsa demi peningkatan kesejahteraan bangsa dan seluruh masyarakatnya.

Pendidikan adalah segala kegiatan pembelajaran yang berlangsung sepanjang jaman dalam segala situasi kegiatan kehidupan. Dalam prakteknya pendidikan yang bersifat desentralisasi belum dapat memenuhi targetnya untuk menyejahterakan pendidikan khususnya untuk daerah-daerah yang terpencil. Adanya ketimpangan antara wilayah satu dengan yang lain terutama menyangkut tenaga pendidik, sarana dan prasarana. Oleh karena itu, pemerintah mulai memberlakukan otonomi di bidang pendidikan. Pembukaan Undang-undang Dasar 1945 menyatakan bahwa salah satu tujuan bangsa Indonesia adalah mencerdaskan kehidupan berbangsa dan bernegara, sehingga untuk itu maka setiap warganegara berhak mendapatkan pendidikan tanpa memandang ras,suku, sosial, etnis, agama dan gender. Kemudian dilanjutkan dengan adanya Undang-undang Nomor 20 Tahun 2003 tentang Sistem Pendidikan Nasional mengamanatkan pendidikan yang menjangkau seluruh masyarakat Indonesia untuk dapat mengenyam pendidikan yang layak. Undang-undang ini memuat tentang visi, misi, fungsi, dan tujuan pendidikan nasional. Undang-undang Nomor 22 Tahun 1999 tentang Pemerintah Daerah juga mendukung adanya pendidikan terutama untuk daerah yang masih jauh terjangkau dengan menjelaskan tentang daerahdaerah dan wilayah yang dapat dikembangkan supaya lebih kreatif, inovatif, dan kreatif. Termasuk di dalamnya adalah budaya-budaya yang terdapat dalam setiap komunitas dan masyarakat Indonesia (Huda, 2010).

Pendidikan Dasar Terpadu pada dasarnya adalahpenyelenggaraan pendidikanyangmencakup sekolah dasar (SD) dan sekolah menengah pertama (SMP) yang sekolah dan atau pengelolaannya terpadu. Keterpaduan yang dimaksud dapat secara fisik dan/atau secara pengelolaan. Keterpaduan secara fisik berarti bahwa lokasi SMP menyatu atau didekatkan dengan SD. Pengembangan sekolah ini merupakan model inovasi pendidikan yang berwujud ide, dimana peserta didik yang telah menyelesaikan pendidikan di jenjang tertentu tidak perlu keluar dari wilayahnya (tempat belajar di tempat ia memperoleh ilmu sebelumnnya) karena tempat belajar pada jenjang yang lebih tinggi berada di satu tempat. Hal tersebut dapat memberi dampak positif, khususnya bagi masyarakat di sekitar. Masyarakat tidak perlu menyekolahkan anaknya keluar dari daerah tempat tinggal mereka yang jaraknya terpencil, terisolasi, dan terpencarpencar. Lokasi geografis yang sulit dijangkau ini menjadi salah satu dasar pemikiran pemerintah dalam mengembangkan pendidikan terpadu untuk mengurangi Angka Partisipas Kasar (APK) daerah tersebut. Sehingga anak-anak juga dapat melanjutkan pendidikan formal tanpa menempuh jarak yang jauh atau berpisah dengan keluarga mereka.

Suku Boti adalah merupakan salah satu suku di daerah Nusa Tenggara Timur. Suku ini merupakan suku tertua yang berada di pulau Timor. Suku Boti adalah suku yang merupakan keturunan asli Pulau Timor, Atoni Metu, Provinsi Nusa Tenggara Timur. Suku Boti terbagi menjadi dua yaitu Boti Dalam dan Boti Luar. Jumlah penduduk Boti dalam sekitar 300 jiwa, sedangkan Boti Luar 2500 jiwa. Suku Boti Dalam memiliki areanya tersendiri yang telah diberi pagar kayu. Desa tersebut terletak di lereng bukit dengan ketinggian $1500 \mathrm{dpl}, 12 \mathrm{~km}$ dari kota Kecamatan Kie dan $60 \mathrm{~km}$ ke arah timur dari Kota Soe, Kabupaten Timor Tengah Selatan dan dapat dijangkau 3 jam dengan kendaraan roda dua. Area dengan luas 3000 meter persegi tersebut selalu tertutup pagar kayu.

Suku ini dikenal sangat memegang teguh keyakinan yang disebut dengan Halaika. Mereka percaya pada dua penguasa alam yaitu Uis Pah dan Uis Neno. Uis Pah sebagai mama atau ibu yang mengatur, mengawasi, dan menjaga kehidupan alam beserta isinya termasuk manusia. Sedangkan Uis Neno sebagai papa atau bapak yang merupakan penguasa alam baka yang akan menentukan seseorang bisa masuk surga atau neraka berdasarkan perbuatannya di dunia. Suku Boti Dalam adalah suku kuno yang tinggal di Kecamatan Kie, Kabupaten Timor Tengah Selatan, di pedalaman Pulau Timor tepatnya di daerah Boti. Karena letaknya yang susah dicapai, maka desa Boti tertutup dari peradaban modern dan perkembangan zaman. Hal tersebut juga berpengaruh terhadap tersalurnya pendidikan formal bagi anak-anak suku Boti di sana. Pendidikan yang seharusnya menjadi perhatian utama pemerintah pun jadi agak sedikit lalai, karena jarak dan medan yang agak 
sulit apalagi untuk membangun sebuah sekolah. Hanya ada satu sekolah yang berdiri di desa Boti dalam yaitu SDN-SMPN Satu Atap Oefau.

Tujuan penelitian adalah: (1) menjelaskan secara mendalam tentang enkulturasi budaya lokal yang terdapat di Suku Boti terhadap pendidikan anak-anak; (2) menguraikan tentang adanya faktor pendukung dan penghambat dalam pengimplementasian budaya lokal Suku Boti terhadap pendidikan; (3) menjelaskan secara mendalam mengenai strategi dalam mengatasi faktor pendukung dan penghambat pendidikan berbasis budaya lokal; dan (4) menganalisis implementasi pendidikan berbasis budaya lokal suku Boti dalam pendidikan yang terdapat di SDN-SMPN Satu Atap Oefau di Desa Boti, Nusa Tenggara Timur.

\section{METODE}

Penelitian ini akan menggunakan penelitian kualitatif dengan rancangan studi kasus. Penelitian kualitatif sendiri berupaya untuk mendapatkan gambaran mendalam dan mengungkapkan pendidikan yang berbasis budaya lokal pada SDNSMPN SATAP Oefau. Penelitian ini digunakan untuk mengungkapkan serta mendeskripsikan data tentang pengembangan pendidikan di dalam Kerajaan Boti yang masih memiliki budaya yang melekat di masyarakatnya. Dalam penelitian kualitatif terdapat tiga tahap utama yaitu: (1) tahap deskripsi atau tahap orientasi, pada tahap ini peneliti mendeskripsikan apa yang dilihat, didengar dan dirasakan, peneliti baru mendata sepintas tentang informasi yang diperolehnya; (2) tahap reduksi, pada tahap ini peneliti mereduksi segala informasi yang diperoleh pada tahap pertama untuk memfokuskan pada masalah tertentu; (3) tahap seleksi, pada tahap ini peneliti menguraikan fokus yang telah ditetapkan menjadi lebih rinci kemudian melakukan analisis secara mendalam tentang fokus masalah (Sugiyono, 2007; Gunawan, 2017). Hasilnya adalah tema yang dikonstruksi berdasarkan data yang diperoleh menjadi suatu pengetahuan, hipotesis, bahkan teori baru.

Ada tiga teknik pengumpulan data yang digunakan, yaitu: (1) wawancara mendalam; (2) pengamatan peran serta; dan (3) dokumentasi. Metode pengumpulan data adalah dengan cara apa dan bagaimana data yang diperlukan dapat dikumpulkan sehingga hasil akhir penelitian mampu menyajikan informasi yang valid dan reliabel. Kegiatan pengumpulan data dan analisis data dalam penelitian kualitatif tidak bisa dipisahkan satu sama lain, karena kesemuanya berlangsung secara simultan. Oleh karena itu, analisis data dalam penelitian ini dilakukan ketika proses penelitian masih berlangsung (on going process) dan analisis pada saat berakhirnya kegiatan penelitian untuk selanjutnya dibuat laporan. Analisis data adalah proses mencari dan menyusun secara sistematis data yang diperoleh dari hasil wawancara, catatan lapangan, dan bahan-bahan lain sehingga dengan mudah dapat dipahami, daan temuannya dapat diinforrmasikan kepada orang lain.

Penelitian kualitatif harus mengungkapkan kebenaran yang objektif. Oleh sebab itu keabsahan data dalam penelitian kualitatif dianggap sangat penting. Untuk mengecek keabsahan data pada penelitian kualitatif menurut Lincoln dan Guba (1986) dapat dilihat dari empat aspek, yaitu: (1) derajad kepercayaan (credebility); (2) kecocokan (transferability); (3) ketergantungan (dependability); dan (4) penegasan (confirmability). Pengecekan keabsahan data dalam penelitian ini dalam penelitian ini akan menggunakan kredibilitas dan konfirmabilitas data. Hal ini dilakukan demi menjamin kebenaran data yang ada (Moleong, 2013; Wiyono, 2007). Fokus studi kasus penelitian ini adalah spesifikasi kasus dalam suatu kejadian baik itu yang mencakup individu, kelompok budaya, ataupun potret kehidupan. Dimana sekolah ini merupakan satu-satunya sekolah yang dekat dengan salah satu suku tertua yang ada di Pulau Timor yaitu Suku Boti.

\section{HASIL}

Suku Boti merupakan salah satu kelompok masyarakat yang masih mempertahankan kesatuan kebudayaan, yaitu kebudayaan Boti. Adanya upacara-upacara adat seperti adat perkawinan, masuk minta, upacara menyambut kelahiran, upacara kematian, dan upacara syukuran panen. Selain itu juga, bangunan rumah mereka masih tradisional, dimana desain rumah masih seperti dahulu yang masih bernuansa Timor yang disebut ume kbubu (rumah bulat) dan lopo (semi rumah bulat yang dipakai untuk duduk berkumpul). Anak-anak yang ada di Suku Boti Dalam diberi 
pemahaman oleh orang tua dan diajar tentang adat istiadat yang berlaku serta aktif dalam setiap kegiatan sosial kebudayaan. Contohnya bergotongroyong mengolah kebun, mengikuti upacara pernikahan, upacara kematian, dan upacara panen. Anak-anak Suku Boti Dalam juga diajarkan sejak dini untuk menggunakan pakaian adat sehari-hari.

Masyarakat maupun usif juga mendukung kegiatan serta dunia pendidikan formal yang sudah ada sejak tahun 1988 namun untuk tetap menjaga kelestarian budaya lokal dahulu hanya ada satu orang dari setiap keluarga yang diijinkan bersekolah formal. Sedangkan lainnya bersekolah alam untuk belajar mengenai bercocok tanam, menenun atau mengukir. Secara geografis sekolah yang masuk ke dalam wilayah Boti dalam ini menjadi salah satu pendorong adanya proses pendidikan berbasis budaya lokal. Sehingga sebagian besar guru-guru memasukan unsur budaya ke dalam kehidupan sehari-hari maupun pelajaran yang diajarkan.

\section{PEMBAHASAN}

Selain adanya faktor pendukung yang mendukung terjadinya proses pendidikan budaya lokal, maka tidak lepas pula dari permasalahan hambatan yang ada. Hambatan itu bisa datang dari guru sendiri, peserta didik, lingkungan keluarga ataupun faktor fasilitas (Munandar, 2002). Muhadjir (2000) menyatakan bahwa pendidikan memiliki arti memperbaiki moral dan melatih intelektual. Sekolah SDN-SMPN Satu atap ini pada awalnya memiliki banyak siswa yang tidak memiliki agama, mereka hanya mempercayai adanya aliran Halaika, yaitu menyembah kepada Tuhan langit dan Tuhan Bumi. Pendidikan formal mengantarkan mereka mengerti arti pendidikan, agama, budaya, dan lain-lain (Mulyasa, 2006).

Sedangkan dalam mengatasi hambatananya, maka Kepala Sekolah beserta jajaran guru-guru berupaya untuk terus meningkatkan 8 standar manajemen pendidikan. Bekerjasama dengan pihak-pihak terkait seperti Dinas Pendidikan kota Soe dan Dinas Pariwisata Kota Kupang menjadi salah satu strategi yang digunakan untuk mengatasi hambatan yang ada di SDN-SMPN Satu atap Oefau. Hal tersebut dikarenakan, wilayah Boti yang telah menjadi wisata Budaya daerah Nusa Tenggara Timur harus didukung faktor-faktor baik internal maupun eksternal. Langkah selanjutnya adalah memfasilitasi guru honorer untuk melanjutkan kuliah, sehingga mereka memiliki kompetensi di bidang pendidikan, khususnya dalam bidang kompetensi dasar dan kompetensi inti. Pembekalan kursus ketrampilan yang lebih berfokus pada orientasi dan pengembangan potensi lokal juga diperlukan oleh SDN dan SMPN Satu Atap Oefau.

Pendidikan berbasis budaya lokal yang terdapat di SDN dan SMPN Satap Oefau, sekolah memiliki model pembelajaran berbasis budaya yang telah diterapkan walaupun belum secara maksimal. Sekolah ini masih memegang nilai budaya dan tradisi yang ada di masyarakat yang sudah sekian lama berada di lingkungan sekolah tersebut. Hal tersebutlah dikarenakan SDN-SMPN menjadi satu-satunya sekolah yang masuk dalam kawasan Boti Dalam. Oleh sebab itu, kepala sekolah membangun pendidikan tanpa melupakan budaya lokal yang ada di sekitar. Tilaar (2002) dalam bukunya mengemukakan bahwa dunia pendidikan perlu dipacu untuk secara terencana dan terarah melahirkan manusia-manusia budaya yang sadar, terdidik, dan berkualitas. Upaya tersebut dilakukan oleh pihak sekolah dengan mewujudkan pembelajaran yang berbasis budaya.

Kebudayaan lokal yang dimiliki oleh suku tersebut merupakan tipologi adanya masyarakat multikultural. Kebudayaan lokal menjadi pemegang peranan penting yang tidak dapat dipisahkan dari kehidupan masyarakat seharihari (Koentjaraningrat, 2002; Gunawan, 2016). Kebudayaan menjadi jantung bagi kehidupan masyarakatnya. Maka, sebuah hal mustahil bila memisahkan masyarakat suku Boti dari kebudayaannya. Kebudayaan sendiri adalah bentuk tingkatan atau jenis perkembangan intelektual atau peradaban tertentu dalam suatu masyarakat (Munandar, 2002; Gunawan dan Sulistyoningrum, 2013). Bisa juga merupakan masyarakat atau kelompok yang memiliki ciri khas adat, perolehan, hasil, pandangan, dan sebagainya. Nilai-nilai dari kebudayaan lokal tersebut kemudian mengajarkan adanya seperangkat etika dan prinsip hidup yang sangat kuat.

Koentjaraningrat (1993) menjelaskan budaya atau kebudayaan berasal dari bahasa sansekerta yaitu buddhayah, yang merupakan bentuk jamak dari buddhi (budi atau akal) diartikan sebagai halhal yang berkaitan dengan budi dan akal manusia. 
Sedangkan menurut Soekanto (2003) kebudayaan yang disebut culture berasal dari bahasa latin colere, yaitu mengolah atau mengerjakan sehingga dapat diartikan pula sebagai mengolah tanah. Kata culture dalam bahasa Indonesia juga terkadang diterjemahkan sebagai kultur. Di sisi lain lahirlahh konsep pendidikan berbasis budaya yang merupakan sebuah konsep pendidikan yang diselenggarakan untuk memenuhi standar nasional pendidikan yang diperkaya dengan keunggulan komparatif dan kompetitif berdasarkan nilai-nilai budaya yang luhur agar peserta didik dapat berperan secara aktif dan mengembangkan potensi yang ada pada dirinya sehingga dapat menghasilkan manusia yang unggul, cerdas, visioner, peka dengan lingkungan dan keberagaman budaya, serta tanggap terhadap perkembangan dunia.

Pendidikan dan kebudayaan yang telah dijabarkan menjadi sesuatu yang krusial untuk dicermati. Kebudayaan tidak dapat dipisahkan dari pendidikan, begitu juga sebaliknya. Pendidikan tanpa adanya budaya menyebabkan lunturnya nilai-nilai kearifan lokal yang ada sedangkan budaya tanpa pendidikan tidak akan memberi manfaat jangka panjang yang berarti. Kekuatan nilai-nilai budaya dapat mempengaruhi jalannya pendidikan. Adanya kekuatan pendidikan digunakan menjadi alat transformasi bagi budaya. Dalam transformasi tersebut pendidikan memiliki fungsi. Salah satunya adalah digunakan sebagai salah satu alat dalam mengembangkan kebudayaan yang ada. Nilai kebudayaan yang ada juga mengajarkan seperangkat etika, nilai hidup dan falsafah yang mendalam bagi siswa yang tinggal dalam lingkungan tersebut. Pendidikan budaya dan pendidikan berbasis budaya adalah salah satu hal yang tidak dapat dipungkiri pada masa sekarang ini.

Fortes sebagaimana dikutip oleh Tilaar (2002) mengemukakan tiga variabel utama dalam transformasi kebudayaan, yaitu: (1) unsur-unsur yang ditransformasikan; (2) proses tranformasi; dan (3) cara transformasi. Unsur-unsur transformasi kebudayaan adalah nilai-nilai budaya, adatistiadat masyarakat, pandangan mengenai hidup serta berbagai konsep hidup lainnya yang ada di dalam masyarakat; berbagai kebiasaan sosial yang digunakan dalam interaksi atau pergaulan para anggota. Seluruh spektrum kebudayaan, antara lain: sistem kepercayaan, bahasa, seni, sejarah, dan ilmu-ilmu dan nilai-nilai yang terkandung di dalamnya hanya bisa dialihkan (ditransformasikan) dari satu generasi ke generasi lain melalui pendidikan dalam arti luas. Pentingnya kesadaran akan sebuah budaya harus ditanamkan sedalam mungkin ke dalam jiwa masyarakatnya namun tentu melalui jalur pendidikan. Dalam hal ini, pendidikan berbasis budaya merupakan alat paling ampuh dalam menanamkan kesadaran berbasis budaya dengan karakter menjadi diri sendiri dan serta melestarikan nilai-nilai kearifan lokal agar masyarakat juga tidak tercabut dari akarnya.

\section{KESIMPULAN DAN SARAN}

\section{Kesimpulan}

Kesimpulan yang dapat diambil dari penelitian tersebut adalah: (1) mengenai pendidikan berbasis budaya lokal bahwa kebudayaan lokal menjadi pemegang peranan penting yang tidak dapat dipisahkan dari kehidupan masyarakat seharihari; (2) pendidikan dan kebudayaan yang telah dijabarkan menjadi sesuatu yang krusial untuk dicermati; (3) kebudayaan tidak dapat dipisahkan dari pendidikan, begitu juga sebaliknya. Pendidikan tanpa adanya budaya menyebabkan lunturnya nilai-nilai kearifan lokal yang ada sedangkan budaya tanpa pendidikan tidak akan memberi manfaat jangka panjang. Saran-saran terkait dengan proses pendidikan di SDN-SMPN Satau Atap Oefau adalah untuk meningkatkan kerjasama dengan pemerintah, dinas pendidikan, Dinas Pariwisata serta pihak-pihak yang dapat membantu melestarikan Budaya Lokal Suku Boti agar tidak tergerus oleh budaya luar.

\section{Saran}

Berdasarkan permasalahan di atas, maka peneliti memberikan saran bagi Pemerintah Daerah sebagai masukan kebijakan supaya lebih meningkatkan peran yang maksimal dalam melestarikan budaya Boti di Kabupaten Timor TengahSelatan. Bagi Dinas Pendidikan,Pemudadan Olahraga, sebagai bahan evaluasi tentang program keunggulan daerah yang telah diinstruksikan dan dimasukan dalam pengembangan kompetensi daerah. Bagi sekolah lain, dapat dipakai sebagai 
rujukan dalam implementasi pendidikan berbasis budaya lokal untuk mendukung kompetensi siswa yang ada. Bagi guru dan masyarakat Boti, dapat dijadikan sebagai tempat dimana pendidikan dan budaya ditanamkan melalui lingkungan kepada anak-anak tanpa melupakan pendidikan itu sendiri. Bagi para peneliti lain sebagai bahan rujukan yang ingin meneliti lebih lanjut mengenai pendidikan budaya lokal di sekolah yang masih satu wilayah dengan suku-suku pedalaman yang sudah mendiami Indonesia.

\section{DAFTAR RUJUKAN}

Gunawan, I. 2016. Pasaran: Menggali Nilainilai Permainan Tradisional dalam Mengembangkan Sifat-sifat Kepemimpinan Pendidikan. Jurnal Studi Sosial, 8(1), 55-64.

Gunawan, I. 2017. Metode Penelitian Kualitatif: Teori dan Praktik. Jakarta: PT Bumi Aksara.

Gunawan, I., dan Sulistyoningrum, R. T. 2013. Menggali Nilai-nilai Keunggulan Lokal Kesenian Reog Ponorogo Guna Mengembangkan Materi Keragaman Suku Bangsa dan Budaya pada Mata Pelajaran IPS Kelas IV Sekolah Dasar. Jurnal Premiere Educandum, 3(1), 50-87.

Huda, M. 2010. Kajian Filosofis Otonomi Daerah Bidang Pendidikan. Malang: FIP Universitas Negeri Malang.

Koentjaraningrat. 1993. Kebudayaan Mentalitas dan Pembangunan. Jakarta: Gramedia.
Koentjaraningrat. 2002. Pengantar Antropologi: Pokok-pokok Etnografi. Jakarta: Gramedia.

Moleong, L. J. 2013. Metodologi Penelitian Kualitatif. Bandung: Remaja Rosdakarya.

Muhadjir, N. 2000. Metode Penelitian Kualitatif. Yogyakarta: Rake Sarasin.

Mulyasa, E. 2006. Kurikulum yang di Sempurnakan. Bandung; PT Remaja Rosadakarya

Munandar, U. 2002. Kreativitas dan Keberbakatan: Strategi Mewujudkan Potensi Kreatif dan Bakat. Jakarta: Gramedia.

Soekanto, S. 2003. Sosiologi Suatu Pengantar. Jakarta: PT Raja Grafindo Persada.

Sugiyono. 2007. Metode Penelitian Kuantitatif, Kualitatif, dan $R \& D$. Bandung: Alfabeta.

Tilaar, H. A. R. 2002. Membenahi Pendidikan Nasional. Jakarta: Rineka Cipta.

Undang-undang Dasar 1945. 2015. Jakarta: Sinar Grafika.

Undang-undang Nomor 20 Tahun 2003 tentang Sistem Pendidikan Nasional. 2014. Jakarta: Fokus Media.

Undang-undang Nomor 22 Tahun 1999 tentang Pemerintah Daerah. 2014. Jakarta: Fokus Media.

Wiyono, B. B. 2007. Metodologi Penelitian Pendekatan Kuantitatif, Kualitatif, dan Action Research. Malang: Universitas Negeri Malang. 